\title{
EFFECT OF SAGO CATERPILLAR (RHYNCOPHORUS BILINETAUS VAR PAPUANUS) OIL EXTRACT AGAINST LYMPHOCYTE, LEUKOCYTE, AND CD4 LEVELS OF HUMAN IMMUNODEFICIENCY VIRUS PATIENTS IN PAPUA, INDONESIA
}

\author{
ROSMIN MARIATI TINGGINEHE*, SARCE MAKABA \\ Faculty of Public Health, Cenderawasih University, Papua, Indonesia. *Email: rosmin_t@yahoo.co.id \\ Received: 29 August 2018, Revised and Accepted: 26 September 2018
}

\section{ABSTRACT}

Objective: Human immunodeficiency virus (HIV)/acquired immune deficiency syndrome has become a pandemic worrying the world community. The HIV virus destroys the human immune system causing the person can lose their immune system so that they are easily infected and die from complications of various diseases. The purpose of this study was to determine whether the administration of sago caterpillars oil extract can increase levels of lymphocytes, leukocyte, and CD4 on HIV patients in Papua.

Methods: The research method utilized a true experiment with a randomized control group design. Data collection techniques included several double-blind stages. The first, selection of sago caterpillar and was done extraction process to get oil then packed into capsules. The second step, intervention in 14 subjects randomly which divided into 3 groups, the group receiving flour extract $(n=5)$, oil extract $(n=5)$, and the control group with placebo $(n=4)$. During the intervention, all subjects were placed in a shelter and got the same food and the same activity.

Results: Based on paired sample test statistical tests, it was found that there were significant differences before and after intervention in the group given oil preparations $(\mathrm{p}=0.023<0.05)$ and control $(\mathrm{p}=0.043<0.05)$. Measurement of leukocyte levels showed that the group of oil and flour preparations had significant differences before and after intervention ( $p=0.040<0.05, p=0.010)$, whereas in the control group, there were no significant differences between before and after administration $(\mathrm{p}=0.182>0.05)$. All intervention groups experienced an increase in CD4 cell count in the blood. The results of paired sample test statistical tests CD4 levels before and after the intervention showed a significant relationship in the three treatment groups $(\mathrm{p}=0.001 ; 0.025 ; 0.015<0.05)$.

Conclusion: The administration of sago caterpillar oil extract gives a significant effect against the rising of lymphocyte, leukocyte, and CD4 level in HIV sufferers blood.

Keywords: Sago caterpillar, CD4, Leukocyte, Human immunodeficiency virus, Patient.

(c) 2018 The Authors. Published by Innovare Academic Sciences Pvt Ltd. This is an open access article under the CC BY license (http://creativecommons. org/licenses/by/4. 0/) DOI: http://dx.doi.org/10.22159/ajpcr.2018.v11i12.29382

\section{INTRODUCTION}

The acquired immune deficiency syndrome (AIDS) is caused by the human immunodeficiency virus (HIV). HIV-1 was initially identified by Luc Montanier at the Institute Pasteur, Paris, in 1983. Since its discovery, almost 70 million people have been infected with the HIV virus, and about 35 million people have died of AIDS. An estimated $0.8 \%$ of adults aged 15-49 years worldwide are living with HIV, although the burden of the epidemic continues to vary considerably between countries and regions. Sub-Saharan Africa remains most severely affected, with nearly 1 in every 20 adults (4.9\%) living with HIV and accounting for $69 \%$ of the people living with HIV worldwide [1,2]

The Papua Province of AIDS Commission (KPA), 2006 reported that the number of HIV sufferers in Papua Province was 25,233 cases of which $98 \%$ of free sex. The highest number of HIV/AIDS sufferers was found in Jayawijaya Regency as many as 5293 cases and Mimika 4524 cases. Based on the age group, the highest number of HIV/AIDS sufferers was in the age range of 25-49 years, which were 5,333 cases and AIDS as many as 9211 cases [3]

Papua government has taken some steps to prevent the spread of HIV by collecting them in one place and living together as ODHA gaining assistance from non-governmental organizations (NGOs), and undergo regular mental and physical health are checked by doctors which appointed by the government. Stage 1 and 2 of HIV sufferers usually work as sex workers (CSWs), due to being pressured by economic needs and family burdens. There are still some people who are free to roam and carry out their sexual activities, both in prostitution, roadside and in the forest. In general, they just mingle with the community, get assistance, and their activities are monitored by NGOs. They checked their health at the hospital and got advice from doctor to take anti-viral drugs and sleeping regularly and eating nutritious foods which could help improve the body's immune system. On the contrary, patients who have gained Stages 3 and 4 begin feeling infections that make him suffer and need help from doctors. Therefore, scientists of Papua have developed a traditional medication which derived from nature to prevent the spread HIV infection.

One of the natural products which are famous in Papua and easy to find it is sago caterpillar (Rhynchophorus bilineatus varpapuanus) containing high nutrients such as amino acid and protein. The concept of nutrient support in an effort to modulate the immune function known as immunenutrition (Immune-enhancing-diets or immune-modulating diets) is a therapeutic approach to pathological changes in both adaptive and natural immunity, which arises secondary to inflammation, infection, or surgery by administering immune nutrients [4].

HIV infection is characterized by a systemic glutathione deficiency [5] which develops only weeks following infection, and by increased oxidative stress [6]. Surprisingly, even given these facts, the role of the glutathione system in the pathogenesis of HIV-associated disease and its impact on the clinical course of the infection is still unclear. The tripeptide glutathione $\mathrm{L}-\gamma$-glutamyl-L-cysteinylglycine $(\mathrm{GSH})$ is essential for metabolic and cell-cycle-related functions in virtually all cells. Its ability to directly scavenge free radicals and to act as a cosubstrate in the glutathione peroxidase catalyzed the reduction of $\mathrm{H}_{2} \mathrm{O}_{2}$ and lipid 
hydroperoxides make GSH central to defense mechanisms against intra- and extra-cellular oxidative stress [7]. In addition, HIV infection is characterized by systemic glutathione deficiency [5] which develops only weeks following infection, and by increased oxidative stress $[7,8]$. Surprisingly, even given these facts, the role of the glutathione system in the pathogenesis of HIV-associated disease and its impact on the clinical course of the infection is still unclear [7]. However, there is a consensus that HIV-infected individuals have subnormal concentrations of GSH and cysteine, as well as of glutamine, the second important glutathione precursor amino acid, in various body compartments.

Regarding this, sago caterpillar has high amino acid content such as cysteine, glycine, glutamate, isoleucine, leucine, and valine. This findings suggested that therapeutic intervention with glutathione or glutathione precursors could stop or at least delay the normal progression of the disease. In a double-blind, placebo-controlled clinical trial low glutathione levels in CD4+ lymphocytes correlated strongly with survival in HIV-infected individuals.

Based on the description above, it is suspected that the possibility of giving sago caterpillar in food can increase lymphocyte, leukocyte, and CD4 blood levels of HIV sufferers in Papua Province.

\section{MATERIALS AND METHODS}

Materials

Sago caterpillars were derived from Yuboi village, Jayapura regency, Papua. All materials and instruments utilized facilities from Phytochemistry Laboratory, Faculty of Pharmacy, Hasanuddin University.

\section{Methods}

\section{Sample preparation of sago caterpillar and evaluation}

The first, all sago caterpillars were done extraction process using organic solvents by maceration for 5 days to gain thick extract. After that, the extract was dried until getting dry extract in powder form. Then, all powder was entered into the capsule. The second, sago caterpillar powder was done $\mathrm{LD}_{50}$ test on mice using doses $0.5 \mathrm{~g}, 1.5 \mathrm{~g}$, and $2.5 \mathrm{~g}$. From the $\mathrm{LD}_{50}$, results were continued by giving of sago caterpillar capsule to patients in Papua.

\section{Study setting}

This was a randomized control group pre-test and post-test design.

\section{Intervention stages}

The research will be conducted in Klimbay Waena, Jayapura, for 1 month. 2 days before the initial data collection, the research subjects had entered the shelter house. The goal is to identify locations and adaptation to other research subjects, including adaptation to the type of food, mealtime, meal portions, and activity schedule they will follow for 30 days where they live together. This research collaborated with NGOs, namely Harapan Ibu Foundation and the Amanda Tania Foundation, which have been active in providing assistance to HIV/AIDS sufferers in Papua Province. After 2 days of adaptation, the $3^{\text {rd }}$ day was carried out an initial examination (physical and biochemical anthropometry measurements) and direct interviews to obtain accurate data about the research subjects. Anthropometric measurements and interviews were directly conducted by the researchers themselves, while for biochemical measurements were carried out by paramedics from Abepura General Hospital.

\section{Lymphocyte, leukocyte, and CD4 examination stages}

Examination of lymphocytes, leukocytes, and CD4 levels of HIV patients was carried out 2 times before and after the intervention. Meanwhile, taking and examining blood samples were carried out by an analysis team from the Abepura Hospital laboratory.

\section{Inclusion criteria}

The inclusion criteria were included in the study:

a. Subjects are HIV sufferers and not AIDS sufferers. b. Subjects had CD4 counts $>200$.

c. Willing and voluntary to be accommodated together, regulated, and monitored for 1 month.

\section{Sampling of research subjects}

Subjects aged between 17 and 42 years (14 people) who were voluntarily included in this study. They were HIV positive sufferers who are in the assistance of Yayasan Harapan Ibu and are always involved in every HIV/ AIDS activity. All HIV sufferers were placed in one house and observed the development of their health for 30 days. 1 month before participating in this research, all research subjects were collected and explained in detail about the planned research activities, and they lived for a month. 2 days after they were collected, a health check was carried out to get preliminary data regarding the subject's health condition and CD4 data in the blood. Initial data taken gave data about body weight, height, and arm circumference (LILA). Measurement of subject weight used digital scales (Seca, Hamburg Germany) with a level of $0.1 \mathrm{~kg}$ accuracy in standing position. Height measurement is done using Microtoice (CMC weighing equipment, London England) with a level of $0.1 \mathrm{~cm}$ accuracy. Arm circumference measurement (LILA) was carried out using flexible, non-elastic plastic tape with a precision scale of $0.1 \mathrm{~cm}$. For biochemical examination was carried out in the laboratory including complete blood tests such as hemoglobin, hematocrit, leukocytes, lymphocytes, and other blood measurements.

Interventions were divided into three groups: P1 was the control group, the group of subjects receiving ARV and placebo, $\mathrm{P} 2$ was the group receiving ARV and oil extracts of sago caterpillar, and P3 was the group receiving ARV and flour extract. After breakfast, lunch or dinner, each subject will be given a capsule that is immediately bribed into his mouth without knowing whether they get the extract of flour, oil, or placebo. This was done so that the researcher believed that the sago caterpillar extract was consumed every 3 times a day. Food consumed by the subject was always new food, with the same type and the same portion, and the same time of administration. They are not permitted to bring or buy food from outside according to the agreement before the study begins. The meal menu changes according to the menu schedule with a frequency of 3 times a day and 1 snack in the afternoon.

\section{Ethical considerations}

The study was carried out after taking Institutional Ethical Committee clearance, and informed consent was taken from the patients and confidentiality maintained.

\section{RESULTS}

\section{Characteristics of research subject}

A total of 14 subjects were included in this study. Data on subject characteristics can be explained in Table 1 .

Table 1 showed the comparison of the characteristics of research subjects from three treatment groups. A total of 13 subjects were women and only 1 male having the age range of $<30$ years as many as 10 people and 4 people more than 30 years. In general, they are from the Sentani, Genyem and Demta tribes who are still in one district, namely Jayapura District Head of Regency, with 10 people, the rest coming from tribes outside the district, namely Wamena, Bintang Mountains and Makassar, each with 1 person. Their marital status is generally not legally bound in marriage as many as 7 people, with a single status of 3 people and the remaining 4 widows. The level of education is generally at the level of education of the high school, vocational high school and college as many as 9 people and the remaining 5 people have junior high school education. As many as 3 subjects of worker (traders, cleaning service, administrative staff in NGOs of 11 people did not work but they carried out household chores everyday. As many as, 13 people do areca nut eating habits which are common for Papuans, and 11 people still smoke and consume alcohol.

\section{Lymphocyte measurement}

Measurement of the difference in the increase in lymphocyte levels can be shown in Fig. 1 and Table 2. 
Table 1: Characteristics of research subject

\begin{tabular}{|c|c|c|c|c|}
\hline $\begin{array}{l}\text { Characteristics of control respondent } \\
\text { n (\%) }\end{array}$ & $\begin{array}{l}\text { The treatment of oil extract } \\
\text { n (\%) }\end{array}$ & $\begin{array}{l}\text { The treatment of flour extract } \\
\text { n (\%) }\end{array}$ & $\begin{array}{l}\text { The total amount } \\
\text { n (\%) }\end{array}$ & $\mathbf{p}$ \\
\hline \multicolumn{5}{|l|}{ Gender } \\
\hline \multicolumn{5}{|l|}{ Male } \\
\hline $0(0.0)$ & $0(0.0)$ & $1(20.0)$ & $1(7.1)$ & 0.379 \\
\hline \multicolumn{5}{|l|}{ Female } \\
\hline $4(100.0)$ & $5(100.4)$ & $4(80.0)$ & 13 (92.9) & \\
\hline \multicolumn{5}{|l|}{ Age } \\
\hline \multicolumn{5}{|l|}{$<30$ years } \\
\hline $3(75.0)$ & $4(80.0)$ & $3(60.0)$ & $10(71.4)$ & 0.769 \\
\hline \multicolumn{5}{|l|}{$\geq 30$ years } \\
\hline $1(25.0)$ & $1(20.0)$ & $2(40.0)$ & $4(28.6)$ & \\
\hline \multicolumn{5}{|l|}{ Ethnic group } \\
\hline \multicolumn{5}{|l|}{ Wamena } \\
\hline $1(25.0)$ & $0(0.0)$ & $1(20.0)$ & $2(14.3)$ & 0.485 \\
\hline \multicolumn{5}{|l|}{ Sentani } \\
\hline $2(50.0)$ & $4(80.0)$ & $1(20.0)$ & $7(50.0)$ & \\
\hline \multicolumn{5}{|l|}{ Genyem } \\
\hline $1(25.0)$ & $0(0.0)$ & $1(20.0)$ & $2(14.3)$ & \\
\hline \multicolumn{5}{|l|}{ Demta } \\
\hline $0(0.0)$ & $1(20.0)$ & $0(0.0)$ & $1(7.1)$ & \\
\hline \multicolumn{5}{|l|}{ Bintang } \\
\hline $0(0.0)$ & $0(0.0)$ & $1(20.0)$ & $1(7.1)$ & \\
\hline \multicolumn{5}{|l|}{ Makassar } \\
\hline $0(0.0)$ & $0(0.0)$ & $1(20.0$ & $1(7.1)$ & \\
\hline \multicolumn{5}{|l|}{ Education } \\
\hline \multicolumn{5}{|l|}{ Low ability } \\
\hline $1(25.0)$ & $1(20.0)$ & $2(40.0)$ & $4(28.6)$ & 0.769 \\
\hline \multicolumn{5}{|l|}{ High ability } \\
\hline $3(75.0)$ & $4(80.0)$ & $3(60.0)$ & $10(71.4)$ & \\
\hline \multicolumn{5}{|l|}{ Marital status } \\
\hline \multicolumn{5}{|l|}{ Widow } \\
\hline $4(100.0)$ & $5(100.0)$ & $1(20.0)$ & $10(71.4)$ & 0.006 \\
\hline \multicolumn{5}{|l|}{ Single } \\
\hline $0(0.0)$ & $0(0.0)$ & $4(80.0)$ & $4(28.6)$ & \\
\hline Occupation & & & & \\
\hline Employee & & & & \\
\hline $1(25.0)$ & $0(0.0)$ & $2(40.0)$ & $3(21.4)$ & 0.298 \\
\hline Unemployment & & & & \\
\hline $3(75.0)$ & $5(100.0)$ & $3(60.0)$ & $11(78.6)$ & \\
\hline Eating areca nut & & & & \\
\hline Yes & & & & \\
\hline $3(75.0)$ & $5(100.0)$ & $5(100.0)$ & 13 (92.9) & 0.260 \\
\hline No & & & & \\
\hline $1(25.0)$ & $0(0.0)$ & $0(0.0)$ & $1(7.1)$ & \\
\hline Smoking & & & & \\
\hline Yes & & & & \\
\hline $3(75.0)$ & $4(80.0)$ & $4(80.0)$ & $11(78.6)$ & 0.979 \\
\hline No & & & & \\
\hline $1(25.0)$ & $1(20.0)$ & $1(20.0)$ & $3(21.4)$ & \\
\hline Drinking alcohol & & & & \\
\hline Yes & & & & \\
\hline $3(75.0)$ & $5(100.0)$ & $4(80.0)$ & $12(85.7)$ & 0.511 \\
\hline No & & & & \\
\hline $1(25.0)$ & $0(0.0)$ & $1(20.0)$ & $2(14.3)$ & \\
\hline The average of CD4 & & & & \\
\hline 541 & 501 & 520 & 519 & \\
\hline
\end{tabular}

\section{Lymphocyte measurement}

Measurement of the difference in the increase in lymphocyte levels can be shown in Fig. 1 and Table 2.

Based on paired sample test statistical tests it was found that there were significant differences before and after the intervention in the group which given oil preparations $(p=0.043<0.05)$ and control $(p=0.023<0.05)$. Meanwhile, in the flour group $(p=0.234>0.05)$, the rise of lymphocyte was not meaningful. ANOVA test explained that there were differences among the control, oil, and flour groups in increasing blood lymphocytes of the study subjects.

\section{Leukocyte measurement}

The results of the biochemical examination of leukocyte levels in the study subjects are shown in Fig. 2 and Table 3.

The results of the sample paired test statistic test on the measurement of leukocyte levels showed that the group given oil preparations and flour preparations had significant differences before and after intervention $(p=0.040<0.05, p=0.010)$. Whereas in the control group, there were no significant differences between before and after administration $(\mathrm{p}=0.182>0.05)$. 


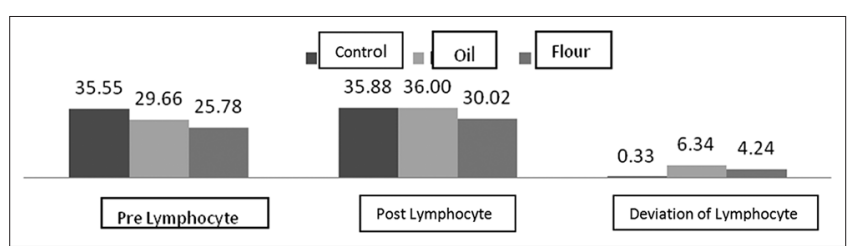

Fig. 1: The comparison of control, oil, and flour groups on lymphocyte levels pre- and post-intervention

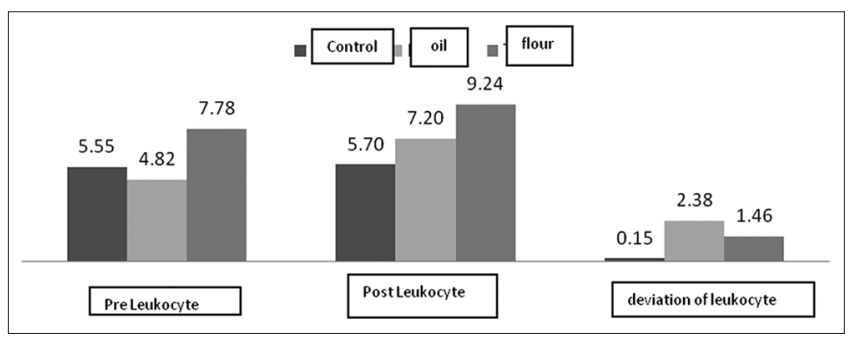

Fig. 2: The comparison of control, oil, and flour groups on leukocyte levels pre- and post-intervention

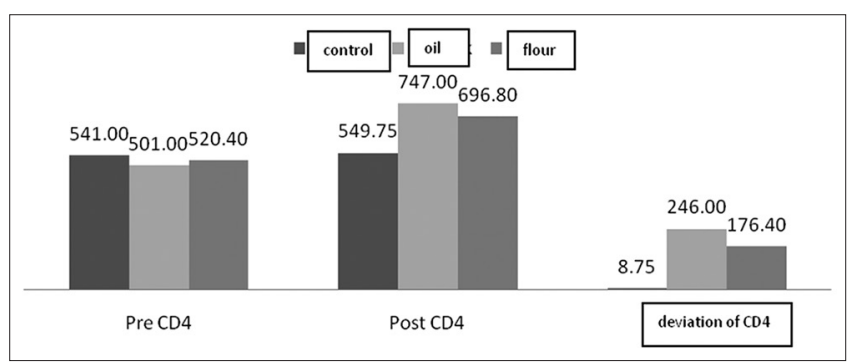

Fig. 3: The comparison of control, oil, and flour groups on CD4 rise pre- and post-intervention

Table 2: The average of lymphocyte pre and post-intervention

\begin{tabular}{lllll}
\hline \multirow{2}{*}{ Group } & \multicolumn{2}{l}{ Lymphocyte } & \multirow{2}{*}{ p value } & Deviation \\
\cline { 2 - 4 } & Pre mean \pm SD & Post mean \pm SD & & \\
\hline Control & $35.55 \pm 9.72$ & $35.88 \pm 9.83$ & $0.043^{* *}$ & $0.33 \pm 0.15$ \\
Oil extract & $29.66 \pm 10.63$ & $36.00 \pm 13.84$ & $0.023^{* *}$ & $6.34 \pm 5.84$ \\
Flour extract & $25.78 \pm 9.28$ & $30.02 \pm 7.36$ & $0.234^{* *}$ & $4.24 \pm 3.06$ \\
P Value & $0.372^{*}$ & $0.205^{*}$ & & $0.030^{*}$ \\
\hline
\end{tabular}

All values are reported as mean $\pm S D(n=3)$. SD: Standard deviation

Table 3: The average of leukocytepre and post intervention

\begin{tabular}{lllll}
\hline Group & \multicolumn{2}{l}{ Lymphocyte } & \multicolumn{3}{c}{ p value } & Deviation \\
\cline { 2 - 4 } & Pre mean \pm SD & Post mean \pm SD & & \\
\hline Control & $5.55 \pm 1.72$ & $5.70 \pm 1.70$ & $0.182^{* *}$ & $0.33 \pm 0.15$ \\
Oil extract & $4.82 \pm 1.05$ & $7.20 \pm 1.55$ & $0.040^{* *}$ & $6.34 \pm 5.84$ \\
Flour extract & $7.78 \pm 0.92$ & $9.24 \pm 2.02$ & $0.234^{* *}$ & $4.24 \pm 3.06$ \\
P Value & $0.008^{*}$ & $0.205^{*}$ & & $0.030^{*}$ \\
\hline
\end{tabular}

All values are reported as mean $\pm S D(n=3)$. SD: Standard deviation

Based on paired sample test statistical tests it was found that there were significant differences before and after the intervention in the group which given oil preparations $(\mathrm{p}=0.043<0.05)$ and control $(\mathrm{p}=0.023<0.05)$. Meanwhile, in the flour group $(\mathrm{p}=0.234>0.05)$, the rise of lymphocyte was not meaningful. ANOVA test explained that there were differences among the control, oil, and flour groups in increasing blood lymphocytes of the study subjects.
Leukocyte measurement

The results of the biochemical examination of leukocyte levels in the study subjects are shown in Fig. 2 and Table 3.

The results of the sample paired test statistic test on the measurement of leukocyte levels showed that the group given oil preparations and flour preparations had significant differences before and after intervention $(\mathrm{p}=0.040<0.05, \mathrm{p}=0.010)$. Whereas in the control group, there were no significant differences between before and after administration $(\mathrm{p}=0.182>0.05)$

\section{CD4 measurement}

Biochemical examination results for CD 4 levels of research subjects are shown in Fig. 3 and Table 4.

The picture above showed that all intervention groups experienced an increase in CD 4 counts in the blood. The results of paired sample test statistical tests CD4 levels before and after the intervention showed a significant relationship in the three treatment groups $(\mathrm{p}=0.001 ; 0.025$; and $0.015<0.05$ ).

\section{DISCUSSION}

Sago caterpillar contains high essential amino acids and unsaturated fatty acids which can boost the immune system in the body. Regarding this, it can be seen by rising of leukocyte, lymphocyte, and CD4 among control, oil, and flour group. This relates to omega 3, 6, and 9, particularly oleic acid in the sago caterpillar. The results of laboratory analysis of the contents of essential amino acids in sago caterpillars showed that is more complete which is the same as the amino acids level in the snakehead fish having function to boost immune system in the human body. The increase in lymphocyte counts in the oil group is caused by sago caterpillar oil formulation and also contains essential fatty acids (omega 3, omega 6, and omega 9) which can stimulate the growth of leukocytes to form self-defense [9].

HIV infection is characterized by an increased oxidant burden and a systemic deficiency of the main antioxidant glutathione which occur early in the course of the disease, long before any clinical manifestations [5,8]. This makes the glutathione system a potential target for adjuvant therapy in HIV-infected patients. The results of the clinical trial reported in this manuscript demonstrate for the $1^{\text {st }}$ time that oral treatment of adult glutathione-deficient patients with advanced HIV-infection with a cysteine-rich nutritional supplement derived from sago caterpillar extract is able to significantly and consistently increase plasma glutathione, leukocyte, lymphocyte, and CD4 levels into the normal range over a period of up to 6 months. Therapy was well tolerated; no clinically meaningful adverse effects were seen.

Several lines of evidence indicate that the glutathione deficiency may be of clinical relevance in the course of HIV infection. First, a beneficial effect of a therapeutic correction of the imbalance between oxidants and antioxidants has been demonstrated in vitro and in vivo $[10,11]$. Second, intracellular glutathione levels of CD4+ lymphocytes predicted survival in HIV-infected individuals while restoration of intracellular glutathione levels by oral NAC increased survival rates of patients in a 2 -year open-label follow-up study [12]. Third, in a recent doubleblind study NAC treatment resulted in a significant improvement of immunological functions of NK-cells and T-cells [13]. The latter points in particular stress were the clinical significance of the systemic glutathione deficiency in HIV infection, and the potential benefit of patients from a therapeutic intervention directed at augmentation of glutathione concentrations [14].

Leukocytes (white blood cell count [WBC]) are the total number of leukocytes. High leukocytes (high WBC count) generally means our body is fighting infection. Nagil, et al., Chynober and Harris and Carrilo and Alonso stated that oleic acid is one of the unsaturated fatty acids which can increase reactive oxygen species production activity and 
Table 4: The average of CD4pre and post intervention

\begin{tabular}{lllc}
\hline \multirow{2}{*}{ Group } & \multicolumn{2}{l}{ Lymphocyte } & p value \\
\cline { 2 - 4 } & Pre mean \pm SD & Post mean \pm SD & Deviation \\
\hline Control & $541.00 \pm 167.92$ & $549.75 \pm 166.5$ & $0.001^{* *}$ \\
Oil extract & $501.00 \pm 181.68$ & $747.00 \pm 314.8$ & $0.025^{* *}$ \\
Flour extract & $520.40 \pm 280.22$ & $696.80 \pm 360.8$ & $0.015^{* *}$ \\
P Value & $0.964^{*}$ & $0.620^{*}$ & $246.00 \pm 156.53$ \\
\hline
\end{tabular}

All values are reported as mean \pm SD $(n=3)$. SD: Standard deviation

has an inhibitory effect on natural killer cell proliferation. Carrilo and Alonso concluded in his study that oleic acid was an anti-inflammatory fatty acid and played an important role in activating different pathways to form body immune cells [15-17].

Branched-chain amino acids (AARC), especially Leucine, Isoleucine, and Valine play an important role, especially during activity and in the maintenance and growth of skeletal muscles. AARC forms approximately $40 \%$ of free essential amino acids in plasma which are used as energy sources during activities, and the process of glyconeogenesis (a mechanism for reusing glucose as energy in muscles) [18]. Besides that, nutritional therapy, especially with AARC supplements, is provided based on an attractive concept at this time to prevent and at the same time complement complementary therapies for opportunistic infections that lead to AIDS [19]. The provision of sago caterpillar extract which is rich in branched chain amino acids and essential fatty acids in HIV patients as early as possible can minimize the potential for wasting in HIV patients, especially those who have lost more than $10 \%$ in the past 6 months. Early nutrition interventions are expected to prevent wasting, improve quality of life and extend the life expectancy of patients.

\section{CONCLUSION}

The data analysis of ANOVA test shows that there is a significant effect between the giving of oil extracts and sago caterpillar powder in increasing the levels of lymphocytes, leukocytes, and CD4 blood of HIV sufferers in Papua Province.

\section{AUTHOR'S CONTRIBUTIONS}

All the authors have contributed equally

\section{CONFLICTS OF INTEREST}

All authors have none to declare.

\section{REFERENCES}

1. HIV/AIDS. Global Health Observatory. Global Situation and Trends. Available from: URL: www.who.int/gho/hiv/en. [Last cited on 2013 Nov 04]

2. Dinakar KR, Narendranath S, Vaneet A, Reshma S, Somashekar HS, Keerthisagar J. Changes in the CD4 counts, hemoglobin and weight in patients with HIV alone and HIV-TB co-infection. Asian J Pharm Clin Res 2014;7:35-8

3. Papua Province AIDS Management Commission. Prevalence of HIV in
Papua. KPA Annual Report; 2016.

4. Mohd NM, Yeo J, Huang MS, Kamarul AM, Koh MT. Nutritional status of children living with HIV and receiving antiretroviral (ARV) medication in the Klang Valley, Malaysia. Malays J Nutr 2011;17:19-30.

5. Buhl R, Jaffe HA, Holroyd KJ, Wells FB, Mastrangeli A, Saltini C, et al. Systemic glutathione deficiency in symptom-free HIVseropositive individuals. Lancet 1989;2:1294-8.

6. Staal FJ. Glutathione and HIV infection: Reduced, or increasedoxidized? Eur J Clin Invest 1998;28:194-6.

7. Van der Ven AJ, Blom HJ, Peters W, Jacobs LE, Verver TJ, Koopmans PP, et al. Glutathione homeostasis is disturbed in CD4positive lymphocytes of HIV seropositive individuals. Eur J Clin Invest 1998;28:187-93

8. Eck HP, Gmunder H, Hartmann M, Petzoldt D, Daniel V, Droge W. Low concentrations of acid-soluble thiol (cysteine) in the blood plasma of HIV-1-infected patients. Biol Chem Hoppe Seyler 1989;370:101-8.

9. Tungadi R, Imran AK. Formulation development and characterization of snakehead fish powder inoral double emulsion. Int J App Pharm 2018;10:70-5.

10. Malorni W, Rivabene R, Lucia BM, Ferrara R, Mazzone AM, Cauda R, et al. The role of oxidative imbalance in progression to AIDS: Effect of the thiol supplier N-acetylcysteine. AIDS Res Hum Retroviruses 1998; 14:1589-96.

11. Boza JJ, Moennoz D, Vuichoud J, Jarret AR, Gaudard-de-Weck D, Ballevre O. Protein hydrolysate vs free amino acid-based diets on the nutritional recovery of the starved rat. Eur J Nutr 2000;39:237-43.

12. Herzenberg LA, De Rosa SC, Dubs JG, Roederer M, Anderson MT, Ela SW, et al. Glutathione deficiency is associated with impaired survival in HIV disease. Proc Nat Acad Sci U S A 1997;94:1967-72.

13. Breitkreuz R, Pittack N, Nebe CT, Schuster D, Brust J, Beichert M, et al. Improvement of immune functions in HIV infection by sulphur supplementation: Two randomized trials. J Mol Med 2000;78:55-62.

14. Aukrust P, Muller F. Glutathioneredox disturbances in human immunodeficiencyvirus infection: Immunologicand therapeutic consequences.Nutrition 1999;15:165-7.

15. Chynober L, Harris RA. Symphosium on branched-chain amino acids: Conference summary, American society for nutrition. J Nutr 2006;236:3335-65.

16. Nagil N, Fleetwood CH, Stewart T. A protein intake is associated with 2012. J Acquir Immun Defic Syn D 2012;5:25-28.

17. Carrilo M, Alonso T. Role of oleic acid in immune system; Mechanism of action; A review. Nutr Hosp 2012;27:978-90.

18. Onwubuya EI, Ukibe NR, Kalu OA, Ukibe SN, Obasi IJ. Assessment of kidney function, estimated glomerular filtration rate and body mass index in Hiv seropositive subjects on antiretroviral therapy in Nnewi. Int J Pharm Pharm Sci 2018;10:44-9.

19. Hussain G, Roychoudhury S, Singha B. Cryptosporidiosis: An emerging enteric disease in Hiv-infected patients, Barak Valley, Assam, India. Int J Pharm Pharm Sci 2016;8:304-6. 